VOX PATRUM $38(2018)$ t. 70

Ks. Bogdan CZYŻEWSKI*

\title{
REGULA MISTRZA O WYBORZE I NAUCZANIU OPATA
}

Rodzące się w Kościele pierwszych wieków klasztory, których inicjatorem i założycielem był św. Pachomiusz, domagały się reguł określających zasady życia ich członków. Na szczególną uwagę w tym względzie zasługuje anonimowe dzieło, od IX w. zwane Regula Magistri ${ }^{1}$. Najkrócej można o nim powiedzieć, że jest starożytnym zbiorem praw monastycznych. Cechą charakterystyczną tego utworu jest bez wątpienia jego długość w porównaniu chociażby z Regułą św. Benedykta ${ }^{2}$. Ciekawy jest też układ zawartych w niej rozdziałów. Mają one mianowicie formę pytań i odpowiedzi. Po Interrogatio dicipulorum, będącym jednocześnie tytułem każdego rozdziału, następuje odpowiedź Pana podana przez Mistrza (Respondit Dominus per magistrum), która stanowi treść poszczególnych rozdziałów³

Bardzo długo, bo prawie do wybuchu II wojny światowej uważano Regułe Mistrza za wywodzącą się z Reguły św. Benedykta. Dopiero mnich z benedyktyńskiego klasztoru w Solesmes, niejaki Augustyn Genestout stwierdził,

* Ks. prof. dr hab. Bogdan Czyżewski - Kierownik Zakładu Teologii Patrystycznej i Historii Kościoła na Wydziale Teologicznym Uniwersytetu im. Adama Mickiewicza w Poznaniu; e-mail: czybo@amu.edu.pl.

${ }^{1}$ Zazwyczaj spotykamy dosyć zwięzłe i podobne do siebie charakterystyki Reguły Mistrza, zwłaszcza w doniesieniu do jej autorstwa oraz wpływu na Regułę św. Benedykta. Por. M. Kanior, Historia monastycyzmu chrześcijańskiego, t. 1: Starożytność (wiek III-VIII), Kraków 1993, 167-168; J. Kłoczowski, Wspólnoty chrześcijańskie w tworzqcej się Europie, Poznań 2003, 71-72.

${ }^{2}$ Badający od wielu lat Regułe Mistrza Adalbert de Vogüé (Wstęp, w: „Reguła Mistrza”. „Reguła” św. Benedykta, ŹM 40, Kraków 2006, 23) twierdzi, że jest ona „dwa razy dłuższa niż większość starożytnych reguł zgromadzonych w Codex Regularum Benedykta z Aniane". Należy nadmienić, że benedyktyn Vogüé (1924-2011) żyjący w Burgundii w opactwie La Pierre-QuiVire opublikował wiele artykułów, studiów i komentarzy na temat Reguly Mistrza i Reguly św. Benedykta. Opracował także krytycznie wydania dwóch wspomnianych Regut. Ojciec T. Dąbek (,,Reguła Mistrza” a ,Reguła” św. Benedykta, w: ŹM 40, 53-55)), który dokonał przekładu Reguty Mistrza uważa niektóre badania Vogüé za zbyt jednostronne i nie zawsze zgadza się z jego tezami, jak chociażby z głębszą zależnością doktrynalną między jedną i drugą Reguła.

${ }^{3}$ Wspomniany Adalbert de Vogüé uważa, że istnieje pewne podobieństwo Reguły Mistrza z Reguła św. Bazylego Wielkiego. Rufin przekładając tę drugą na łacinę wprowadził także podział na Interrogationes et Responsiones. Zbliża je także obszerność (42 strony in-folio Reguty Bazylego, 66 natomiast Reguty Mistrza). Ponadto Vogüé (Wstęp, s. 24) twierdzi, że „koncepcja Mistrza, by jeszcze bardziej rozwinąć własna legislację, jak również nadać jej formę dialogu, powstała prawdopodobnie w trakcie lektury tekstu Bazylego". 
że Reguła Mistrza była źródłem dla Reguły św. Benedykta, a nie odwrotnie, jak do tej pory utrzymywano. Tego samego zdania był hiszpański benedyktyn Mateo del Alamo ${ }^{4}$. Według Genestouta Mistrz żył w początkach V w., między 500 a 530 r., w Dacji, na południe od Rzymu, w otoczeniu Nicetasa z Remezjany ${ }^{5}$. Dalsze lata przyniosły kolejne publikacje, w których wykazywano prawdziwość tezy Genestouta ${ }^{6}$.

Nie znamy autora Reguly Mistrza. Był nim prawdopodobnie opat niewielkiego klasztoru, bo liczącego dwudziestu sześciu mnichów, który pozostawał pod wpływami Rzymu. Dokładna lektura Reguły pozwala określić jej autora jako człowieka niezwykle starannego, dokładnego, biorącego pod uwagę najdrobniejsze szczegóły życia mogące wydarzyć się w kierowanej przez niego wspólnocie. Przeznaczona była dla jednego konkretnego klasztoru?

Wspomniane zostało, że klasztor, dla którego napisana została Reguła Mistrza był niewielki. Mieszkała w nim wspólnota składająca się z dwóch dziesiątek mnichów mających pod dwóch przełożonych (praepositi), opata ( $a b$ bas) oraz bezpośrednio mu podlegającego szafarza (cellarius). Najważniejszy oczywiście w tej grupie osób był opat, zwany niekiedy nauczycielem (Abbas, doctor $)^{8}$. Wynikało to $\mathrm{z}$ tego, że nauczał i kierował klasztorem określonym mianem „szkoły służby Pańskiej (Dominici schola servitii)" ". Opat jako najważniejsza osoba w całej strukturze monastycznej nie tylko nauczał braci i był dla nich mistrzem, ale uważano go za ustanowionego dla wspólnoty przez samego Boga. Kilka rozdziałów Reguty zawiera bezpośrednie wskazania odnoszące się do sposobu wyboru opata ${ }^{10}$ i najistotniejszych zadań ${ }^{11}$, jakie do niego należały. Dlatego też tylko ta problematyka stanie się przedmiotem niniejszego opracowania ${ }^{12}$.

1. Wybór i usuwanie opata. Podejmując najpierw temat wyboru opata przez poprzednika, musimy od razu zaznaczyć, że przypomina on przyjęte zasady przy wyborze papieża w pierwszych latach VI wieku ${ }^{13}$. Odpowiednie

${ }^{4}$ Por. M. Alamo, La Règle de S. Benoît éclairée par sa source, la Règle du Maître, RHE 34 (1938) 739-745.

${ }^{5}$ Por. A. Genestout, La Règle du Maître et la Règle de S. Benoît, RAM 21 (1940) 51-112.

${ }^{6}$ Chodzi tutaj m.in. o następujące opracowania: P.B. Corbett, The Latin of the Regula Magistri, Louvain 1958; A. de Vogüé, La communauté et l'Abbé dans la Règle de saint Benoît, Paris 1961; tenże, Études sur la Règle de saint Benoît, Vie monastique 34, Bellefontaine 1996, 473-495.

${ }^{7}$ Por. M. Starowieyski, Reguła Mistrza. Wprowadzenie, w: Starożytne Reguly Zakonne, PSP 26, Warszawa 1980, 157.

${ }^{8}$ Por. Regula Magistri XC 40, PL 88, 1040, thum. T.M. Dąbek, ŹM 40, Kraków 2006, 340.

${ }^{9}$ Tamże, Thema 45, PL 88, 952, ŹM 40, 90.

${ }^{10}$ Chodzi tutaj o rozdziały XCII-XCIV.

${ }^{11} \mathrm{O}$ zadaniach opata mówią rozdziały II-VI Reguły Mistrza.

${ }^{12}$ W całym tekście Reguly Mistrza spotykamy bardzo wiele odniesień do opata, chociażby różnego rodzaju upomnień i zaleceń kierowanych pod adresem braci.

${ }^{13}$ Por. Vogüé, Wstęp, s. 47. 
przepisy regulujące ten proces znajdują się w końcowej części Reguły Mistrza, zaraz za zasadami określającymi przyjmowanie do wspólnoty tych, którzy pragnęli wstąpić do klasztoru. W trzech przedostatnich rozdziałach mowa jest o wyborze opata (XCII-XCIV). Reguła mówi o podwójnym sposobie, w jakim może się to dokonać. Należy zaznaczyć, iż nie czynili tego mieszkańcy klasztoru, tylko żyjący opat wyznaczał swojego następcę. Był to pierwszy sposób, w jaki dokonywano wyboru. Poprzedzony był jednak dosyć skrupulatną procedura. Polegała ona na swoistym ,konkursie o pierwsze miejsce" ${ }^{\prime 14}$. Chodziło o wywołanie zdrowego współzawodnictwa, które nie było rozumiane jako wyścig o władzę, co raczej pożyteczne dla dusz zakonników zabieganie o długotrwałą wierność w cnocie. Mieszkańcy klasztoru zdawali sobie sprawę z tego, o czym zresztą często informował ich opat, że przed swoją śmiercią wybierze on swojego następcę. Będzie nim ten, kto okaże się najbardziej wierny regule, stąd też wspomniane współzawodnictwo nie miało nic wspólnego z negatywnym pojmowaniem tego słowa. Chodziło bardziej o ustawiczna troskę braci, by ciągle postępować w dobrym i nieustannie doskonalić swoje życie. Dlatego Reguła uwrażliwiała opata, by wybierając swojego następcę miał na względzie, czy będzie on w stanie wypełnić nałożone na niego obowiązki, ponieważ ,jeżeli ktoś najpierw nie będzie we wszystkim doskonałym uczniem, nie będzie mógł być godnym Mistrzem"15.

W Regule mowa jest też o konieczności unikania przez opata wyznaczania sobie wcześniej pomocnika, który mógłby wydawać się mieszkańcom klasztoru za wybranego z góry następcę ${ }^{16}$. Dlatego powinien kolejno każdemu kazać siadać ze sobą do stołu, stawać przy sobie w kaplicy i rozpoczynać psalmy. Dzięki temu uniknie się wynoszenia wyznaczonej osoby nad pozostałymi braćmi a zaszczepi w nich przekonanie, że ,zaszczytny urząd będzie obiecany tym, którzy postępują dobrze i święcie" ${ }^{17}$. Każdy zatem miał szansę, by zostać wybrany na opata, bez wcześniejszego przyrzeczenia tego komukolwiek bądź też wyraźnego faworyzowania kogokolwiek. Liczyła się przede wszystkim świętość życia oraz starania wszystkich w klasztorze, by okazywali się „,coraz lepszymi w dobrej gorliwości i pragnieniu zaszczytu"18. $\mathrm{Z}$ jednej strony

${ }^{14}$ Regula Magistri XCII 7-10, PL 88, 1045, ŹM 40, 353-354: „[...] zawsze powinien opat mówić wszystkim braciom: Bracia i synowie moi, kto z was to wypełni, by słuchając we wszystkim Bożych przykazań i we wszystkim będąc posłusznym regule, okazać się podobnym do moich czynów, ktokolwiek osiagnie to, że wypełni czynami moją naukę, ktokolwiek swoje obyczaje podda poprawie i będzie postępował nie w swojej własnej woli i osądzie, lecz w posłuszeństwie Bogu przeze mnie".

${ }^{15}$ Tamże XCII 32, PL 88, 1046, ŹM 40, 355.

${ }^{16}$ Por. tamże XCII 1-2, PL 88, 1045, ŹM 40, 353: „Opat powinien się strzec, by czasem nie ustanowił sobie kogoś na drugim albo trzecim miejscu. Dlaczego? Aby, gdy nikogo nie wyniesie i nie da mu zaszczytnego miejsca i gdy obieca, że po sobie zaszczytne miejsce wyznaczy temu, kto święcie postępuje, na pewno sprawi, że wszyscy skłonią się do dobrych uczynków i pokory".

${ }^{17}$ Tamże XCII 41, PL 88, 1046, ŹM 40, 355.

${ }^{18}$ Tamże XCII 51, PL 88, 1046, ŹM 40, 356. 
wspomniane pragnienie osiąnięcia zaszczytnego miejsca we wspólnocie nie musiało być czymś negatywnym, co raczej mobilizującym do wierności przepisom reguły oraz okazywania Bogu i opatowi tego co dobre i święte. Z drugiej jednak strony współzawodnictwo mogło wprowadzać do życia mnichów wyraźne wypaczenie $w$ ich ascezie. Bracia wiedzieli, że któryś z nich zostanie wybrany na opata, dlatego uprawiane przez nich cnoty były z myślą o ludzkim „sukcesie”, do tego dozorowane przez drugiego człowieka. Mogło zatem zabraknąc w ich postawach autentycznego, niezakłamanego postępowania opartego o prawdziwą pobożnośćc ${ }^{19}$.

Zadanie wyboru następcy nie było zatem sprawą łatwą. Opat musiał bowiem być uważnym obserwatorem a jednocześnie dobrym psychologiem, by przekonać się, czy sposób postępowania poszczególnych mnichów był szczery. Miał zwłaszcza brać pod uwagę, „kto spośród różnych w zawodach okazał się wyższym w zachowaniu zasad życia i doskonalszym w życiu zakonnym"20. $\mathrm{Z}$ czysto ludzkiego punktu widzenia można jednak mieć wątpliwości, na ile taki wybór był właściwy, przede wszystkim zaś wtedy, gdy opat był już w ,słusznym" wieku a jego rozeznanie odnoszące się do postaw zakonników było mocno osłabione przez lata życia, a co za tym idzie, związane z nimi wszelkie dolegliwości. O tego typu trudnościach Reguła nie wspomina, można jedynie mieć pewność, iż opierano się na głębokim przekonaniu, że wyborem opata kierował sam Bóg, człowiek natomiast pozostawał jedynie narzędziem w Jego rękach. Wydaje się, że takie przeświadczenie towarzyszyło opatowi, ponieważ w chwili wyboru swojego następcy zapewniał, iż to Trójca Swięta skłoniła go do takiego a nie innego wyboru ${ }^{21}$.

Autor Reguły dokładnie też relacjonuje, w jaki sposób ma przebiegać ustanowienie wybranego kandydata. Kiedy stary opat poczuje zbliżającą się śmierć lub poważnie zachoruje ${ }^{22}$, powinien zwołać całą wspólnotę i od razu wypowiedzieć wobec niej imię swojego następcy, bądź wziąć go za rękę i wyznać, że spośród wszystkich „w zachowywaniu wszelkich nakazów Bożych, to jest $\mathrm{w}$ milczeniu, w posłuszeństwie, we wierze, w pokoju, w łasce, $\mathrm{w}$ cierpliwości, w dobroci, w prostocie, w czujności, w trzeźwości, w umiarkowaniu, w czystości, zawsze był lepszym"23 od pozostałych. Ustępujący opat zapewniał też wspólnotę, że brat ten wybrany zostaje na pasterza całej wspólnoty na mocy Bożego postanowienia oraz jego świadectwa, należy zatem przyjać tę decyzję jako wolę samego Boga ${ }^{24}$.

${ }^{19}$ Por. Vogüé, Wstęp, s. 47. Ten sam autor pokazuje w jednym ze swoich opracowań, że mimo wielu mankamentów odnoszących się do tzw. pedagogicznych wynalazków Mistrza, które zawarł w swojej Regule, bilansu tego monumentalnego dzieła nie można uznać za całkowicie negatywny; por. A. de Vogüé, Faut-il mettre le Maître en enfer?, CCist 57 (1995) 132-145.

${ }^{20}$ Regula Magistri XCII 72, PL 88, 1046, ŹM 40, 358.

${ }^{21}$ Por. tamże XCII 77, PL 88, 1047, ŹM 40, 358.

${ }^{22}$ Por. tamże XCIII 56, PL 88, 1048, ŹM 40, 363.

${ }^{23}$ Tamże XCII, 78-82, PL 88, 1047, ŹM 40, 358.

${ }^{24}$ Por. tamże XCIII 1-5, PL 88, 1047-1048, ŹM 40, 359. 
Od momentu przedstawienia wspólnocie wybranego na urząd opata następowało jego ustanowienie w uroczystym obrzędzie. W Regule czytamy, że „,po tym natychmiast wszyscy pomodlą się i wezwie się zwierzchnika kościoła i świadectwo jego urzędu duchownego"25. Pierwszym zatem aktem była wspólna modlitwa mnichów i prośba skierowana do miejscowego biskupa, by $\mathrm{z}$ racji pełnionego urzędu przewodniczył ustanowieniu nowego opata. Następnie biskup wpisywał w spisach opatów imię nowo wybranego zaraz po imieniu jego poprzednika (mutato episcopi manu nomine eius in abbatis honorem, in diptico post nomen prioris eius) i odprawiał Mszę św. w intencji nowego opata. Reguła zastrzega też, by za życia poprzedniego opata imię jego wymieniać jako pierwsze, nowego zaś jako drugie. Chodziło zapewne o wspomnienie imienia opata w modlitwie eucharystycznej ${ }^{26}$. Po zakończonej Mszy św. ustępujący z urzędu opat oraz wszyscy członkowie zakonnego zgromadzenia, w obecności biskupa i towarzyszących mu osób ${ }^{27}$ przekazywali znak pokoju nowemu opatowi (data ei a priore pace, vel subsequente congregatione). Następnie poprzedni opat podawał mu do ręki regułę (tradat ei in manum regulam), klucze od spiżarni (petitas claves a cellario) oraz spis ,wszystkich rzeczy i narzędzi, i ksiąg, i wszystkich ruchomości i świadectwa wszystkich rzeczy przyniesionych przez poszczególnych braci" ${ }^{28}$. Obrzęd ten przypominał przekazanie całej własności klasztoru na ręce nowego opata. Towarzyszyło temu pouczenie wypowiadane przez ustępującego opata, który uzasadniał, co oznacza wspomniane przekazanie reguły, kluczy i majątku zakonnego. Gdy idzie o regułę, opat zwracał się do nowego opata w takich słowach:

„Weź, bracie, jako prawo Boże tę regułę, przez którą będziesz przedstawiał życie wieczne tym, którzy jej przestrzegaja, a zapowiadał wieczny sąd tym, którzy ją lekceważą. Tu dusza zwycięża lub ginie, tu traci się życie albo zachowuje. Na podstawie tego Bóg rozliczy cię z nadzoru nad duszami, których strzeżesz”29.

Opat uświadamiał swojego następcę, że ciąży na nim odpowiedzialność za wspólnotę, zwłaszcza zaś za uczenie jej członków wiernego przestrzegania zakonnej reguły. Od tego bowiem zależeć będzie ich przyszłość: szczęście

${ }^{25}$ Tamże XCIII 6, PL 88, 1048, ŹM 40, 359.

${ }^{26}$ Por. tamże XCIII 8-10, PL 88, 1048, ŹM 40, 359: „Niech duchowny odprawi Mszę przy ołtarzu w kaplicy, składając Ofiarę za tego brata. Jeżeli jednak opat jeszcze nie umrze i jeszcze nie zostanie zabrany spośród żywych, wtedy (imię nowego opata wymieni się) po imieniu starszego. Albowiem potem, gdy imię zmarłego przejdzie między spoczywających (w pokoju), będzie się pisało imię nowego na pierwszym miejscu".

${ }^{27}$ Reguła wymienia ich dosyć enigmatycznie. Raz czytamy, że „wezwie się zwierzchnika kościoła tej okolicy i świadectwo jego urzędu biskupiego" (tamże XCIII 6, PL 88, 1048, ŹM 40, 359), innym razem, że chodzi o „wszystkich członków urzędu duchownego” (tamże XCIII 11, PL 88, 1048, ŹM 40, 360).

${ }^{28}$ Tamże XCIII 13, PL 88, 1048, ŹM 40, 360.

${ }^{29}$ Tamże XCIII 15-18, PL 88, 1047-1048, ŹM 40, 360. 
oglądania Boga, bądź też skazanie siebie na potępienie za ignorowanie przepisów reguły.

O podobnej odpowiedzialności mówił opat swojemu następcy w odniesieniu do tego, co stanowiło majątek klasztoru:

„Z tego spisu stada będziesz musiał po mnie zdać sprawę na sądzie Bożym. Pamiętaj, pamiętaj, bracie, pamiętaj, że «komu więcej powierzono, tym więcej od niego żądać będą» (Łk 12, 48) i bądź już gorliwy i nie myśl, że jesteś bezpieczny od paszczy żarłocznego wilka i przyszłych zasadzek diabelskich przeciw twemu stadu" ${ }^{30}$.

Niezwykle wymowne jest trzykrotne powtórzenie słowa ,pamiętaj” (memento). Sprawia ono wrażenie ojcowskiej troski o następcę, ale stanowiło też wyraźne ostrzeżenie, by w żaden sposób nie lekceważyć odpowiedzialności związanej z przejmowanym urzędem. Mądre i uczciwe gospodarowanie dobrami materialnymi było równie ważne jak zachowywanie zakonnej reguły.

Kolejnym aktem wprowadzenia nowego opata w urząd było nałożenie na niego płaszcza (pallium), który do tej pory był własnością poprzedniego opata, ucałowanie jego ręki i wejście wraz z całą wspólnota, która od tej chwili stała się jego własnością, do kaplicy ${ }^{31}$. Następnie „stojąc na miejscu poprzednika po odmówieniu przez kapłana modlitwy za niego", nowy opat podchodził do ołtarza i składał „na nim regułę, którą otrzymał" 32 . Potem odmawiano werset psalmu: „Umocnij, Boże, to co zdziałałeś w nas” (Ps 68[67], 29), z modlitwą „Chwała” oraz wykonywano śpiew. Po śpiewie nowy opat wraz z całą wspólnotą zakonną leżał na posadzce kaplicy krzyżem czemu towarzyszyła modlitwa. Kiedy wstał całował kolana biskupa ${ }^{33}$ (osculetur genua sacerdotis), ten zaś podnosił go i przekazywał mu znak pokoju (erigatur ei ad pacem). Podobny gest czynił biskup i nowy opat w odniesieniu do uczestników uroczystości. Przekazywali ,znak pokoju wszystkim z urzędu biskupiego, potem przełożonym i całemu zgromadzeniu" ${ }^{34}$. Według zapisu zawartego w Regule: „,i tak zakończy się (uroczystość zgodnie) z dyscypliną" ${ }^{35}$, był to ostatni obrzęd, poprzez który ustanawiano nowego opata. Można jednak odnieść wrażenie, iż dalsze przepisy także należały do tego, co nazwaliśmy liturgicznym wprowadzeniem w urząd opata. Nowy opat oddawał bowiem osobiście klucze szafarzowi (tradens claves manu sua cellario), modlił się ze wszystkimi, prosił biskupa o błogosławieństwo (petita benedictione) i siadał na katedrze poprzednika (in cathedra sedeat praedecessoris). Następnie przełożeni

${ }^{30}$ Tamże XCIII 19-22, PL 88, 1048, ŹM 40, 360.

${ }^{31}$ Por. tamże XCIII 27-29, PL 88, 1048, ŹM 40, 361.

32 Tamże CXIII 29-30, PL 88, 1048, ŹM 40, 361.

${ }^{33}$ W Regule jest mowa o kapłanie, chodziło jednak o biskupa, ponieważ dalej jest mowa o przekazaniu znaku pokoju ,wszystkim z urzędu biskupiego” (tamże XCIII 34, PL 88, 1048, ŹM 40, 361), co z całą pewnością oznacza osoby towarzyszące biskupowi.

34 Tamże XCIII 35, PL 88, 1049, ŹM 40, 361.

35 Tamże XCIII 36, PL 88, 1049, ŹM 40, 361. 
i pozostali członkowie wspólnoty całowali mu kolana (omnes eius genua osculentur). Po tym geście oddania i wzajemnej miłości nowy opat podchodził do leżącego jeszcze na ziemi poprzednika, całował jego kolana (osculetur genua eius), składał mu pokłon i prosił go o przekazanie mu znaku pokoju (porrigatur ad pacem ei) ${ }^{36}$.

Opat mógł faktycznie objąć powierzony mu urząd dopiero po śmierci poprzednika. Za jego życia nie wolno mu było wykonywać żadnej funkcji związanej z zaszczytem, który go spotkał. Miał okazywać jedynie gorliwość w przestrzeganiu reguły, skromność oraz głęboką pokorę ${ }^{37}$. Nie oznacza to jednak odsunięcia go od wszystkich przywilejów opata. Uznawany był od tej chwili za drugiego, ponieważ wybrał go Bóg, opat ten wybór potwierdził, biskup zaś go ustanowi ${ }^{38}$. Dlatego miał zajmować miejsce w chórze naprzeciw opata i przewodniczyć w kaplicy odmawiającym psalmy, po nim też spożywał Eucharystię i traktowany był w klasztorze jako najważniejszy po opacie ${ }^{39}$. W razie zaś nieobecności opata, miał ,prawo poprawiać występki braci i karać przez wyłączenie" ${ }^{40}$. Pełnił zatem funkcję zastępcy nieobecnego opata.

Wybranie i ustanowienie nowego opata nie oznaczało jeszcze, że mógł być on pewny swojego urzędu. W razie bowiem wykonywania funkcji zastępcy opata, gdy ten udał się w podróż, a okazał się jej niegodny przez pychę, niedbałość, nieprzestrzeganie przepisów reguły i brak należytej pokory, mógł zostać pozbawiony powierzonego mu zaszczytu. Procedura w takim przypadku była stosunkowo prosta. Uznany za niegodnego opat podlegał karze wyłączenia przez wykreślenie jego imienia ręką biskupa ze spisu opatów. Otrzymywał też niższe miejsce w hierarchii klasztornej, czyli nie mógł stawać, jak do tej pory, przy boku opata, opat zaś rozpoczynał poszukiwania nowego kandydata, lepszego od tego, który został usunięty ${ }^{41}$.

Autor Reguły Mistrza brał także pod uwagę drugą możliwość wyboru opata. Zachodziła ona wówczas, gdy urzędujący opat nagle umierał i nie zdążył wyznaczyć swojego następcy. Przepis pod tym względem był jednoznaczny i wyraźny. Nikt nie mógł dokonać wyboru samego siebie, ponieważ byłby to nie tylko brak pokory, ale także możliwość zaistnienia niebezpieczeństwa rozłamu w klasztorze:

„Aby ktoś biorąc następstwo według własnego sądu, nie pobudził wszystkich do buntu i walka grup o władzę uczyniłaby zamieszanie w domu pokoju i obróciła go w pole bitwy"42.

\footnotetext{
${ }^{36}$ Por. tamże XCIII 37-39, PL 88, 1049, ŹM 40, 361-362.

${ }^{37}$ Por. tamże XCIII 43-55, PL 88, 1049, ŹM 40, 362-363.

${ }^{38}$ Por. tamże XCIII 62, PL 88, 1049, ŹM 40, 363.

${ }^{39}$ Por. tamże XCIII 63-65, PL 88, 1049-1050, ŹM 40, 363-364.

${ }^{40}$ Tamże XCIII 66, PL 88, 1050, ŹM 40, 364.

${ }^{41}$ Por. tamże XCIII 69-90, PL 88, 1050, ŹM 40, 364-366.

${ }^{42}$ Tamże XCIV 5, PL 88, 1051, ŹM 40, 367.
} 
Reguła poleca, by wyborem zajął się biskup. Wyznaczał on innego opata, który zamieszkiwał przez trzydzieści dni pośród braci jako ich przełożony i obserwował każdego brata ${ }^{43}$. Czas ten potrzebny był do tego, by rozeznać, który z zakonników byłby najbardziej odpowiedni i najlepiej nadawał się na funkcję opata. Po upływie trzydziestu dni, w obecności biskupa, duchowieństwa oraz całego zgromadzenia, wybierający opata składał „przysięgę na najświętszą Ewangelię, iż nikt nie przekupił go przyrzeczeniami lub pochlebstwami, lecz to, co znalazł dla tej sprawy Bożej, w całości ogłosi" ${ }^{44}$. Dopiero po tym zapewnieniu i wskazaniu kandydata można było ustanowić go przełożonym nad wspólnotą według wyżej już omówionego sposobu.

2. Sposób nauczania opata. Jaki powinien być opat? Pytanie to zadaje w Regule uczeń Mistrzowi, na które otrzymuje w miarę wyczerpującą odpowiedź. Już w pierwszym zdaniu Mistrz podkreśla z naciskiem, iż opat ,w klasztorze zastępuje Chrystusa", co wynika z samego określenia go słowem opat, czyli ojciec (łac. abbas, aram. $a b b a)^{45}$. Jest on dla swoich uczniów nie tylko przełożonym, ale przede wszystkim ojcem, podobnie jak każdy chrześcijanin, zgodnie ze słowami św. Pawła, jest przybranym dzieckiem Boga i może zwracać się do Niego „Abba, Ojcze” (por. Rz 8, 15). Z powodu porównania do samego Chrystusa, według autora Reguły, „opat nie powinien niczego uczyć (docere), ani postanawiać (constituere), ani rozkazywać (iubere), co by wykraczało poza przykazania Pańskie"46. Jego nauczanie musi zatem mieścić się całkowicie w granicach nauki zawartej w Ewangelii i nie może wymagać on czegoś, co byłoby jej zaprzeczeniem. Ten jakże ważny postulat można rozumieć na dwa sposoby. Po pierwsze, jako ostrzeżenie przed groźbą zniekształcenia doktryny Kościoła i przekazywanie jej mnichom w fałszywym świetle. Po drugie zaś, autor Reguty przestrzega, by stawiane mieszkańcom klasztoru wymagania były zgodne z tym, czego od swoich uczniów żąda Chrystus. Zarówno polecenia, jak i nauka przekazywana przez opata winny „rozsiewać w duszach uczniów zaczyn Bożej sprawiedliwości" ${ }^{47}$, co oznaczało budowanie w ich sercach Królestwa Bożego.

Jak ważna jest poprawna nauka w klasztorze, świadczą słowa Mistrza o odpowiedzialności opata za nauczanie i posłuszeństwo uczniów. Dlatego autor Reguły z takim naciskiem podkreśla, zwracając się do opata, by zawsze pamiętał, ,że na straszliwym sądzie Bożym zda sprawę z obojga: ze swego nauczania i z posłuszeństwa uczniów (doctrinae suae, vel discipulorum obedientiae)" ${ }^{\prime 4}$. Dodaje też, iż ,jeśli kiedykolwiek uszczerbek pożytku znajdzie

\footnotetext{
${ }^{43}$ Por. tamże XCIV 6-8, PL 88, 1051, ŹM 40, 367-368.

44 Tamże XCIV 9, PL 88, 1051, ŹM 40, 368.

${ }^{45}$ Por. tamże II 1, PL 88, 955, ŹM 40, 100.

46 Tamże II 4, PL 88, 955, ŹM 40, 100.

${ }^{47}$ Tamże II 5, PL 88, 955, ŹM 40, 100.

48 Tamże II 6, PL 88, 955, ŹM 40, 100.
} 
Ojciec rodziny w owcach, to wina będzie przypisana pasterzowi" ${ }^{49}$. Odpowiedzialność opata bywała jednak pomniejszona a nawet stawał się on całkowicie wolny od jakiejkolwiek winy w przypadku, gdy mnisi okazywali się nieposłuszni względem niego, mimo że gorliwie ich nauczał i napominał ${ }^{50}$. Oni sami mieli ponieść surową karę śmierci wiecznej za to, że byli „owcami opornymi wobec starań pasterza" 51 .

$\mathrm{Z}$ tego, co do tej pory zostało powiedziane, sformułować można konkretny wymóg stawiany opatowi. Powinien on przede wszystkim odznaczać się prawością w nauczaniu i rozwijać u swoich uczniów posłuszeństwo względem Boga. Musiał czynić to gorliwie, by nikt nie zarzucił mu w tym względzie opieszałości bądź też zaniedbań. Opat był tym, który kierował „szkołą służby Pańskiej (Dominici schola servitii)" "52. Reguła dokładnie też określa, czego opat powinien nauczać braci. Znajdujemy w niej swoisty katalog mądrości, które należało zaszczepiać uczniom, cnót, które musieli rozwijać i wreszcie przedkłada niejako spis grzechów, których powinni się wystrzegać ${ }^{33}$. Wszystko to zaś nazwane zostało ,świętą sztuką (ars sancta)", której opat zobowiązany był uczyć uczniów w klasztorze określonym jako ,pracownia (monasterii officina)" ${ }^{24}$.

Zadanie nauczania zostaje w Regule dosyć szczegółowo sprecyzowane i omówione. Ma ono przybrać podwójne niejako oblicze, mianowicie poprzez słowo i przykład życia. Autor Reguły zachęca nawet opata do tego, by drugi sposób dominował nad pierwszym: „niech więcej czynami niż słowami (factis amplius quam verbis) uczy wszystkiego dobrego i świętego" ${ }^{55}$. Mistrz nie ogranicza się tylko do takiego stwierdzenia, ale wyjaśnia, co ma na myśli mówiąc o nauczaniu słowem i przykładem:

„Niech uczniom pojętnym przykazania Pańskie słowami przedkłada (mandata Domini proponat), a tym którzy są twardego serca i prostakom niech nakazy Boże w swych czynach objawia (factis suis divina praecepta monstret). Niech jego czyny ucza, że nie należy robić tego wszystkiego, co jako naganne uczniom swoim przedstawił, aby nie okazał się godnym potępienia ten, który głosił kazania dla innych"s6.

${ }^{49}$ Tamże II 7, PL 88, 955, ŹM 40, 100.

${ }^{50}$ Por. tamże II 8-9, PL 88, 955, ŹM 40, 100-101: „Jeśli natomiast pasterz okazał wszelką gorliwość względem trzody niespokojnej i nieposłusznej, jeśli na wszelki sposób usiłował uleczyć ich chore postępki, to będzie na sądzie Pańskim uniewinniony i Panu powie z Prorokiem: «Sprawiedliwości Twojej w mym sercu nie ukryłem, prawdę Twoją i zbawienie głosiłem, oni mnie zaś zlekceważyli i wzgardzili» (Ps 40[39], 11; Iz 1, 2)”.

${ }^{51}$ Tamże II 10, PL 88, 955, ŹM 40, 101.

${ }^{52}$ Tamże Thema 45, PL 88, 952, ŹM 40, 90.

${ }^{53}$ Por. Vogüé, Wstęp, s. 25.

${ }^{54}$ Regula Magistri II 52, PL 88, 956, ŹM 40, 105. Wspomniany katalog mądrości stanowią cztery rozdziały III-VI, PL 88, 957-959, ŹM 40, 106-116.

${ }^{55}$ Tamże II 12, PL 88, 955, ŹM 40, 101.

${ }^{56}$ Tamże II 12-13, PL 88, 955, ŹM 40, 101. 
Z tekstu wynika, że we wspólnocie klasztornej spotkać można było różnych mnichów. Jedni okazywali się otwarci na głoszone nauki zawarte w Bożym słowie i przyjmowali je jako polecenia samego Boga, by zgodnie z nimi prowadzić życie mnicha. Inni zaś, określeni przez Mistrza niezwykle dosadnie jako „twardego serca” (duris corde) i ,prostacy” (simplicites), mieli z pewnością ogromne trudności nie tylko z wsłuchiwaniem się w nauki opata, lecz także z wcielaniem ich w życie. Mistrz poleca więc, by tych nie tyle uczyć słowem, które i tak nie przyniesie upragnionego skutku, co raczej przykładem życia. Opat powinien przede wszystkim pokazywać, że sam żyje głoszonymi przez siebie słowami. Nie wolno też zapominać opatowi, że słowo Boże nie odnosi się tylko do słuchających, ale zwłaszcza do tych, którzy je proklamują. Mistrz przestrzega, że kiedy zapomina się o tym, wówczas można usłyszeć skargę Boga wyrażoną w psalmie: „Czemu ty opowiadasz o mojej sprawiedliwości, a usta twoje czemu mówią o moim przymierzu? Ty zaś znienawidziłeś karność" (Ps 50[49], 16-17). Do takich głosicieli odnoszą się też słowa Chrystusa, który zarzuca swoim uczniom, że dostrzegają źdźbło w oku swego brata, belki natomiast we własnym nie widzą (por. Mt 7, 3) ${ }^{57}$.

Do tematu nauczania autor Reguty powraca kilkakrotnie. W jednym $\mathrm{z}$ fragmentów radzi opatowi, by zawsze stosował się do wskazówek św. Pawła mówiącego: „Upominaj, proś i gań $(2 \mathrm{Tm} 4,3)$ " 58 . Cytując Apostoła Narodów, Mistrz wyjaśnia, w jaki sposób należy interpretować owe rady. Według niego opat winien mieć przede wszystkim na względzie kogo naucza i musi dostosować swoje postępowanie do okoliczności:

„niech przeplata pochwały groźbami, niech raz okazuje surowość nauczyciela, raz znowu dobroć ojca. A więc powinien surowiej upominać niekarnych i niespokojnych; posłusznych zaś, łagodnych i cierpliwych prosić, aby postępowali w dobrym" 59 .

Z dzisiejszego punktu widzenia powyższa metoda wydaje się być trudna a nawet niemożliwa do przyjęcia, ponieważ tak naprawdę prowadzi do całkowicie odwrotnego skutku. Okazywanie surowości wobec słabych duchowo i nieposłusznych powoduje strach u wychowanków i sprzyja temu, że ich postępowanie stanie się nieszczere. Taki jednak sposób wychowania, oparty na karności, spotkać można prawie we wszystkich starożytnych regułach zakonnych: groźby i straszenie karami za jakiekolwiek wykroczenia w klasztorach.

3. Najważniejsze pouczenia kierowane do opata. Autor Reguły zwraca uwagę na kilka ważnych przymiotów, czy też cech, jakimi powinien charakteryzować się opat, o których mówi w kierowanych do niego pouczeniach. Chodzi mianowicie o równe traktowanie wszystkich mnichów. Dlatego Mistrz

\footnotetext{
${ }^{57}$ Por. tamże II 14-15, PL 88, 955-956, ŹM 40, 101.

${ }^{58}$ Tamże II 23, PL 88, 956, ŹM 40, 102.

${ }^{59}$ Tamże II 24-25, PL 88, 956, ŹM 40, 102.
} 
przestrzega opata: „Niech nikogo w klasztorze nie wyróżnia. Niech nie kocha jednego więcej niż drugiego" ${ }^{60}$. Zaleca jeszcze więcej mówiąc, że powinien zastąpić im rodziców, czyli być dla nich ,jak matka miłująca jednakowo wszystkie swe dzieci i jak ojciec okazujący im jednakową dobroć" ${ }^{61}$. Taki sposób traktowania mnichów przez opata jak swoich synów wynika, zdaniem autora Reguly, z odnoszenia się do nas przez Boga. On bowiem nie robi różnicy między ludźmi (por. Rz 2, 11), wszyscy jesteśmy jednym w Chrystusie (por. Ga 3,28), co więcej, ,pod jednym Panem pełnimy jednakową służbę wojskową" ${ }^{2}$. Mimo to Mistrz nie jest do końca konsekwentny, ponieważ przewiduje pewne odejście od sformułowanej wyżej zasady jednolitego traktowania mieszkańców klasztoru. Jest zdania, że większa miłość należy się temu, kto „jest lepszy przez dobre uczynki" ${ }^{63}$. Swoje racje uzasadnia tym, że Bóg daje przykład takiego postępowania względem ludzi: „O tyle tylko Bóg nas wyróżnia, o ile okazujemy się lepsi od innych dzięki dobrym uczynkom i pokorni" ${ }^{64}$.

Mówiąc o przymiotach, jakimi winien charakteryzować się opat Reguta wskazuje także na pokorę. Nie może on wywyższać się i pokazywać, że jest od innych lepszy. Autor Reguty przypomina ewangeliczną scenę, w której Jezus stawia przed apostołami dziecko i mówi, że kto chce być pierwszy powinien stać się tak mały i pokorny jak ono (por. Mt 18, 2-4) ${ }^{65}$. Z pokorą wiąże się jeszcze jedna ważna umiejętność, której domaga się od opata Reguła. Czytamy w niej następujące polecenie:

„Przeto cokolwiek opat nakaże czynić uczniom ze względu na Boga (pro Deo agendum), on sam powinien najpierw to czynić, aby we wszystkim, co nakaże, członki naśladowały to, do czego prowadzi je głowa" ${ }^{\circ 6}$.

Powyższy przekaz wydaje się jasny. Opatowi nie wolno stawiać mnichom wymagań, które były dla niego obce. On sam jako najwyższy przełożony w klasztorze powinien je osobiście przeżyć i doskonale wypełniać. W ten sposób stawał się dla swoich uczniów prawdziwym nauczycielem, który pokornie podchodził do wszelkich nakazów nakładanych na braci i sam był w stanie stwierdzić, czy są możliwe do wykonania. Mowa jest oczywiście o nakazach „,ze względu na Boga”, co można rozumieć, że chodzi tutaj o takie wymagania, które prowadzą mnicha do świętości i doskonałości.

W Regule spotykamy też przepis dotyczący tego, by opat pamiętał o odpowiedzialności przed Bogiem za sprawowany przez niego urząd. Nie wolno mu zapominać „kim jest (quod dicitur)” i ,jaki mu tytuł przysługuje (plus ab eo

\footnotetext{
${ }^{60}$ Tamże II 16, PL 88, 956, ŹM 40, 101.

${ }^{61}$ Tamże II 31, PL 88, 956, ŹM 40, 103.

${ }^{62}$ Tamże II 19, PL 88, 956, ŹM 40, 102.

${ }^{63}$ Tamże II 17, PL 88, 956, ŹM 40, 102.

${ }^{64}$ Tamże II 20, PL 88, 956, ŹM 40, 102.

${ }^{65}$ Por. tamże II 26-28, PL 88, 956, ŹM 40, 102-103.

${ }^{66}$ Tamże II 29, PL 88, 956, ŹM 40, 103.
} 
exigitur) ${ }^{\text {"67 }}$. Jest przede wszystkim ojcem dla wspólnoty i „,podją się kierowania duszami", stąd też ,winien przygotować się do zdania z nich rachunku"68. Chodzi tutaj oczywiście o sąd Boży, przed którym stanie po swojej śmierci i niezależnie od liczby braci, „których miał pod swoją opieką”, za każdego będzie rozliczany przed Panem. Autor Reguty niezwykle jasno określa stopień odpowiedzialności opata przed Bogiem. Musi być zawsze

„przezornym Mistrzem (cautus magister), aby wszystko, co rozkazuje (ut omnia quae imperat), czego naucza (omnia quae docet), co poprawia (omnia quae emendat), okazywało się zgodne z przykazaniami Bożymi uczącymi sprawiedliwości (de praeceptis Dei, iustitia dictante, monstrentur), aby nie zostało potępione na przyszłym sądzie" $"$.

Wierność ewangelicznym zasadom została zdecydowanie podkreślona w Regule, stanowi ona jednocześnie obronę opata na sądzie Bożym. Może być spokojny o oceną stawianych przez niego we wspólnocie wymagań, jeżeli nie stały one w sprzeczności z Bożym Prawem.

Odpowiedzialność opata nie ogranicza się jednak wyłącznie do powierzonych mu ludzi, lecz także odpowie on kiedyś przed Bogiem za swoje czyny. Dwukrotnie w Regule zostało podkreślone, że „będzie musiał zdać sprawę $\mathrm{z}$ własnego życia (redditur de suis sollicitus)" "’o. Może być jednak spokojny o swoją przyszłość, ,jeżeli przez swoje napomnienia służył innym do uwolnienia się z błędów" "11. Dzięki takiej postawie może liczyć na wyzwolenie się od własnych wad i grzechów.

Ostanie pouczenie, na jakie wskazuje Reguła w związku z opatem dotyczy sposobu podejmowania decyzji w sprawach odnoszących się do klasztoru. Ma czynić to nie w pojedynkę, ale wszelkie przedsięwzięcia powinien konsultować z braćmi. Reguła nie ogranicza wspomnianej rady do określonej grupy osób, ale wyraźnie precyzuje, iż opat ,powinien zasięgać rady wszystkich (omnium quaeratur consilium)" "72. Uzasadnia to w ten sposób, że wielość opinii sprawia większy komfort dla opata, który może wybrać najlepszą z nich. Poza tym, klasztor nie stanowi własności opata, ,ale rzecz klasztorna należy do wszystkich i (zarazem) nie należy do nikogo (res monasterii omnium est, et nullius est)" "73. Trudność tej wypowiedzi polega na tym, że zawiera ona nielogiczny sposób rozumowania i sprawia wrażenie wzajemnego wykluczania się. Autor Reguly interpretuje ten zapis w ten sposób, że klasztor „należy do wszystkich, bo zachowując kolejność, bracia w klasztorze kolejno wypełniają

\footnotetext{
${ }^{67}$ Tamże II 32, PL 88, 956, ŹM 40, 103.

${ }^{68}$ Tamże II 33, PL 88, 956, ŹM 40, 103.

${ }^{69}$ Tamże II 37-38, PL 88, 956, ŹM 40, 104.

70 Tamże II 39, PL 88, 956, ŹM 40, 104; II 34, PL 88, 956, ŹM 40, 103.

${ }^{71}$ Tamże II 40, PL 88, 956, ŹM 40, 104.

72 Tamże II 44, PL 88, 956, ŹM 40, 104.

${ }^{73}$ Tamże II 48, PL 88, 956, ŹM 40, 104-105.
} 
wszystkie obowiązki i nawzajem oczekują tego od innych"74. Chodzi tutaj zwłaszcza o poszczególne funkcje spełniane we wspólnocie, które czynią ich współodpowiedzialnymi za to wszystko, co dzieje się w klasztorze. Bracia podejmując per turnum zadania w klasztorze służą nie tylko innym braciom, ale też podejmują odpowiedzialność za to wszystko, co się w nim znajduje. Z wyjaśnieniem spotykamy się też w przypadku drugiej części niejasnego zdania, mianowicie, co należy rozumieć przez to, że klasztor nie należy do nikogo. Otóż nie należy do nikogo, ponieważ „w klasztorze nikt nie domaga się od braci, by uznawano coś za jego szczególną własność, niczego nie uważa za swoje ani nie narzuca własnej woli"75. Prawdziwa wspólnota traktuje wszystko, co stanowi klasztor i co się w nim znajduje jako należące do wspólnoty, nikt zaś nie może uznawać czegokolwiek za należące do niego.

Rozwiązanie, by pytać o radę wszystkich, wydaje się być niebezpieczne, chociażby w sytuacji, kiedy mamy do czynienia z dużą ilością braci w klasztorze. Pytanie wszystkich o radę mogło bowiem prowadzić do nieuporządkowanej dyskusji i przedstawiania swoich racji jako najlepszych rozwiązań. Wydaje się, iż autor Reguty przewidział tego rodzaju trudność i dlatego zamieścił przepis, że „bracia nie powinni przemawiać z własnej inicjatywy lub z własnej woli, lecz z polecenia i nakazu opata winni podawać swoje rady"76. Nie było zatem mowy o zabieraniu głosu przez braci w klasztorze, kiedy nie zostali zapytani i brakowało wyraźnego przyzwolenia ze strony opata.

Mogła jednak zaistnieć jeszcze jedna trudność, mianowicie opat nie był usatysfakcjonowany z żadnej podanej mu przez braci rady. Wówczas Reguła poleca, by opat ,zdając się na własny sąd, postanowił to, co zechce i jest rzeczą właściwą aby członki postępowały według uznania głowy"77. Nie wolno zapominać, iż w klasztorze wszyscy pozostawali pod władzą opata, on też podejmował decyzje w oparciu o przedstawiane mu rady, tak samo czynił, kiedy ich brakowało bądź też wydawały mu się niewłaściwe. Mimo wzywania braci na radę i pytania ich o zdanie w kwestiach klasztoru, niezależnie od podjętych decyzji, wspólnota zakonna zawsze musiała okazać się posłuszna decyzjom opata.

$$
* * *
$$

Podsumowując należy podkreślić, że Reguła Mistrza zawierała niezwykle precyzyjne przepisy odnoszące się do opata sprawującego najwyższą i najważniejszą władzę w klasztorze. Ciekawa jest długa procedura wyboru opata. Dokonywał jej poprzednik, kiedy intuicyjnie wyczuwał zbliżającą się śmierć bądź też poważnie zachorował. Obserwowanie braci, dopingowanie ich w zdobywaniu cnót i doskonałości życia sprawiały wrażenie rywalizacji,

\footnotetext{
74 Tamże II 49, PL 88, 956, ŹM 40, 105.

75 Tamże II 50, PL 88, 956, ŹM 40, 105.

76 Tamże II 43, PL 88, 956, ŹM 40, 104.

77 Tamże II 47, PL 88, 956, ŹM 40, 104.
} 
która z jednej strony mogła wydawać się pożyteczna, ponieważ prowadziła do utrwalania w sobie świętości. Stanowiła bowiem czynnik motywujący, aby pilnie i pokornie wypełniać Bożą naukę oraz żyć zgodnie z regułą klasztorną. $Z$ drugiej zaś stawała się niebezpieczna, gdyż istniało realne zagrożenie pojawienia się pośród braci ludzkiej zazdrości, asceza zaś mogła być przez mieszkańców wypaczona i pojmowana wyłącznie w kategoriach osiągnięcia ludzkiego sukcesu, nie zaś narzędzia prowadzącego mnicha do doskonałości.

Po dokonanym wyborze kandydat był wprowadzany na urząd opata przez miejscowego biskupa w specjalnym obrzędzie liturgicznym. W Regule spotykamy również przepisy odnoszące się do ewentualnego usunięcia ustanowionego już opata, który za życia poprzednika okazał się człowiekiem mało pokornym i niewłaściwym na tym urzędzie. Reguła mówi też, co należy zrobić w przypadku nagłej śmierci opata, który nie zdążył dokonać wyboru swojego następcy.

Drugi ważny temat, jaki pojawia się na kratach Reguty Mistrza w związku z osobą opata dotyczył funkcji nauczania. Opat był dla braci przede wszystkim mistrzem, zwłaszcza gdy chodziło o przekazywaną żywymi słowami naukę. Za najważniejszy jednak w tym nauczaniu autor Reguly uznał przykład życia opata, jego wierność przepisom reguły klasztornej, ciagłe ćwiczenie się w cnotach i zaletach, unikanie grzechów. Dzięki pielęgnowaniu tych zalet mógł być prawdziwym nauczycielem w ,szkole służby Pańskiej”, jaką był klasztor.

Reguła Mistrza dostarcza też opatowi konkretnych rad w formie pouczeń, jakim człowiekiem winien być on we wspólnocie. Za najważniejsze z nich uznano pokorę, dalej równe traktowanie braci, następnie świadomość odpowiedzialności za innych oraz za siebie, i w końcu kolegialne zarządzanie klasztorem, które objawiało się w pytaniu wszystkich członków wspólnoty o zdanie. Ostateczną jednak decyzję we wszystkich kwestiach zawsze podejmował opat.

\section{CHOOSING AND TEACHING OF THE ABBOT \\ IN THE RULE OF THE MASTER}

\section{(Summary)}

The monasteries which were raised in the Church in first centuries demanded rules stating life of their members. The initatior and founder of these monasteries was saint Pashomius. It's noteworthy to remind anonymous work which were made in nine century called The Regula Magistri. This extensive ancient opus containing collection of monastic rules written by author of unknown name, was created in about fifth century south of Rome. Nowadays, we assume that The Regula Magistri became a model for the rule of Saint Benedict. The Rule of the Master was written for the monastery where the leading role was up to Abbot. He was the one who was preaching, teaching and he, indeed, was a master for his dis- 
ciples. Several chapter of this monumetal work is dedicated to the rules and procedures of choosing the abbot. It also contains list of the most important tasks which belonged to his office - these are the subject of this study. What's interesting is that, the new abbot was being elected by his predecessor when he sensed that he is going to die shortly or serious ill makes him incapable of continuing his tasks. Abbot was looking after his brothers and encouraged them to acquire virtues. This kind of challenge could seem useful, because it was the motivating factor to, fulfill God's will with dignity and humble, and also to life by the abbey's rules. On the other hand, it could also had been dramatic, because the ascetic way of life sometimes was understood only in human succes category. The candidate was introduced on his duty by local bishop in special liturgical rite. There were also rules dedicated to possibly removal of the abbot, who - when his predecessor still lived - seemed to be unhumble and improper man for this office. The Rule also contains special instruction for the situation, when abbot dies in sudden death and had not decided who would have been his successor. The author of the Master's Rule also draws attention to the manner of teaching conducted by the Abbot. The most important was the testimony of life, fidelity to the binding rules, exercising in virtues and avoiding sins. The Rule of the Master teach the Abbot, that he should be humble, treat the brothers equally, be responsible for the others and for himself, and ask as all brother for the opiniong in issues relating to the monastery.

Key words: abbot, the Rule, teaching, choice, humility, monastery.

Słowa kluczowe: opat, reguła, nauczanie, wybór, pokora, klasztor.

\section{BIBLIOGRAFIA}

\section{Źródła}

Regula Magistri, PL 88, 943-1052, tłum. T.M. Dąbek: Reguła Mistrza, w: „Reguła Mistrza”. ,,Reguła” św. Benedykta, ŹM 40, Kraków 2006, 65-371.

Opracowania

Alamo M., La Règle de S. Benoît éclairée par sa source, la Règle du Maître, RHE 34 (1938) 739-745.

Corbett P.B., The Latin of the Regula Magistri, Louvain 1958.

DĄBEK T.M., ,,Reguła Mistrza” a ,,Reguła” św. Benedykta, w: „,Reguła Mistrza”. ,, Reguta”'sw. Benedykta, ŹM 40, Kraków 2006, 51-64.

Genestout A., La Règle du Maître et la Règle de S. Benoît, RAM 21 (1940) 51-112.

Kanior M., Historia monastycyzmu chrześcijańskiego, t. 1: Starożytność (wiek III-VIII), Kraków 1993.

KŁoczowski J., Wspólnoty chrześcijańskie w tworzqcej się Europie, Poznań 2003.

Starowieyski M., Reguła Mistrza. Wprowadzenie, w: Starożytne Reguły Zakonne, PSP 26, Warszawa 1980, 156-160.

VogüÉ A. DE, Études sur la Règle de saint Benoît, Vie monastique 34, Bellefontaine 1996, 473-495.

VoGüÉ A. DE, Faut-il mettre le Maître en enfer?, CCist 57 (1995) 132-145. 
VogüÉ A. De, La communauté et l'Abbé dans la Règle de saint Benoît, Paris 1961.

VogüÉ A. DE, Wstęp, w: „Reguła Mistrza”. „Reguła” św. Benedykta, ŹM 40, Kraków 2006, 23-49. 